\title{
IMPLEMENTASI STEGANOGRAFI LSB DENGAN ENKRIPSI VIGENERE CIPHER PADA CITRA
}

\section{Implementation of LSB Steganography with Vigenere Cipher Encryption in Image}

\author{
Niria Laila ${ }^{1}$, Anita Sindar RMS ${ }^{2}$ \\ ${ }^{1,2}$ STMIK Pelita Nusantara \\ Jl. Iskandar Muda No.1, 20154 Medan Indonesia \\ Email: 1nirialaia51@gmail.com, ${ }^{2}$ haito_ita@yahoo.com
}

Received 13 / 11 / 2018, Revised 20 / 11 / 2018, Accepted 27 / 11 / 2018

\begin{abstract}
Message encoding is an art and science to maintain news or data, learn mathematical techniques related to aspects of information security such as data confidentiality, data validity, data integrity, and data authentication. The process of encoding and inserting messages with the Vigenere Cipher and LSB methods is the first step in inputting text and keyword files, then text files and keywords are converted into decimal numbers, then processed according to the Vigenere Cipher formula, the cipher text is then transformed into binary form it is inserted into the image by means of each bit of the ciphertext in the last bit of the image, so it is expected that the data sent is not easy to read by third parties. The vigenere cipher algorithm and the LSB (Last Significant Bit) technique can be used as a solution for the security of secret messages that are inserted into the image, can be re-revealed exactly the same as the original form and do not experience the slightest damage.
\end{abstract}

keywords - Message Password, Stenography, LSB, Vigenere Cipher.

\section{Pendahuluan}

Penyandian pesan merupakan seni dan ilmu untuk menjaga berita atau data. Selain pengertian tersebut terdapat pula pengertian ilmu yang mempelajari teknik-teknik matematika yang berhubungan dengan aspek keamanan informasi seperti kerahasiaan data, keabsahan data, integritas data, serta autentikasi data. Ilmu atau seni ini banyak diterapkan disemua bidang, khususnya bidang militer dan agen rahasia. Di dalam ilmu kriptografi, pesan disembunyikan dengan "diacak" melalui proses enkripsi atau disandikan sehingga tidak mudah diketahui oleh orang lain. Permasalahan yang muncul adalah pesan yang teracak (disandikan) dapat dengan mudah mengundang kecurigaan [1].

Untuk menghindari kecurigaan tersebut, maka metode kriptografi dapat dikombinasikan dengan ilmu steganografi. Teknik LSB merupakan teknik yang akan penulis gunakan dalam proses penyembunyian pesan ke dalam citra, karena metode ini paling sederhana, cepat dalam proses penyisipan dan ektraksi pesan, serta mempunyai kapasitas penyisipan yang cukup besar [2].

Salah satu metode kriptografi yang dapat digunakan adalah sandi Vigenere (Vigenere Cipher). Metode vigenere merupakan metode klasik yang pada masa kejayaannya metode ini merupakan metode yang tak terpecahkan. Kelebihan sandi vigenere yaitu sandi ini tidak begitu rentan terhadap metode pemecahan sandi yang disebut analisis frekuensi [3]. 
Sandi ini dikenal luas karena cara kerjanya yang mudah dimengerti dan dapat dijalankan dengan cepat, dan bagi para pemula sulit dipecahkan. Pada saat kejayaannya, sandi ini dijuluki le chiffre indéchiffrable (bahasa Prancis: 'sandi yang tak terpecahkan'). Metode ini dinamakan tes Kasiski karena Friedrich Kasiski-lah yang pertama mempublikasikannya. Setelah pesan dienkripsi dengan menggunakan Vigenere Cipher, maka selanjutnya bit-bit cipher (hasil enkripsi) disisipkan pada bit terakhir dari setiap warna piksel di dalam suatu citra digital [4]. Dengan hanya mengubah bit terakhir (least significant bit) dari setiap warna piksel, maka bit cipher dapat disisipkan tanpa mengubah citra aslinya. [5].

\section{Landasan Teori}

\subsection{Steganografi}

Steganografi merupakan Seni komunikasi rahasia dengan menyembunyikan pesan pada objek yang tampaknya tidak berbahaya. Steganoggrafi adalah jenis komunikasi tersembunyi, yang secara harafiah berarti "tulisan tertutup". Pesannya terbuka, selalu terlihat, tetapi tidak terdeteksi bahwa adanya pesan rahasia [6].

Metode-metode umum dalam sebuah digital images antara lain [7] :

\section{Least Significant Bit Insertion (LSB)}

Perubahan yang dihasilkan terlalu kecil, sehingga sulit dikenali oleh mata manusia. Kekurangan dari teknik ini adalah karena teknik ini menggunakan setiap pixel dalam sebuah citra, format kompresi yang menjaga keutuhan data seperti bmp atau gif harus digunakan sebagai citra Gambar 1.

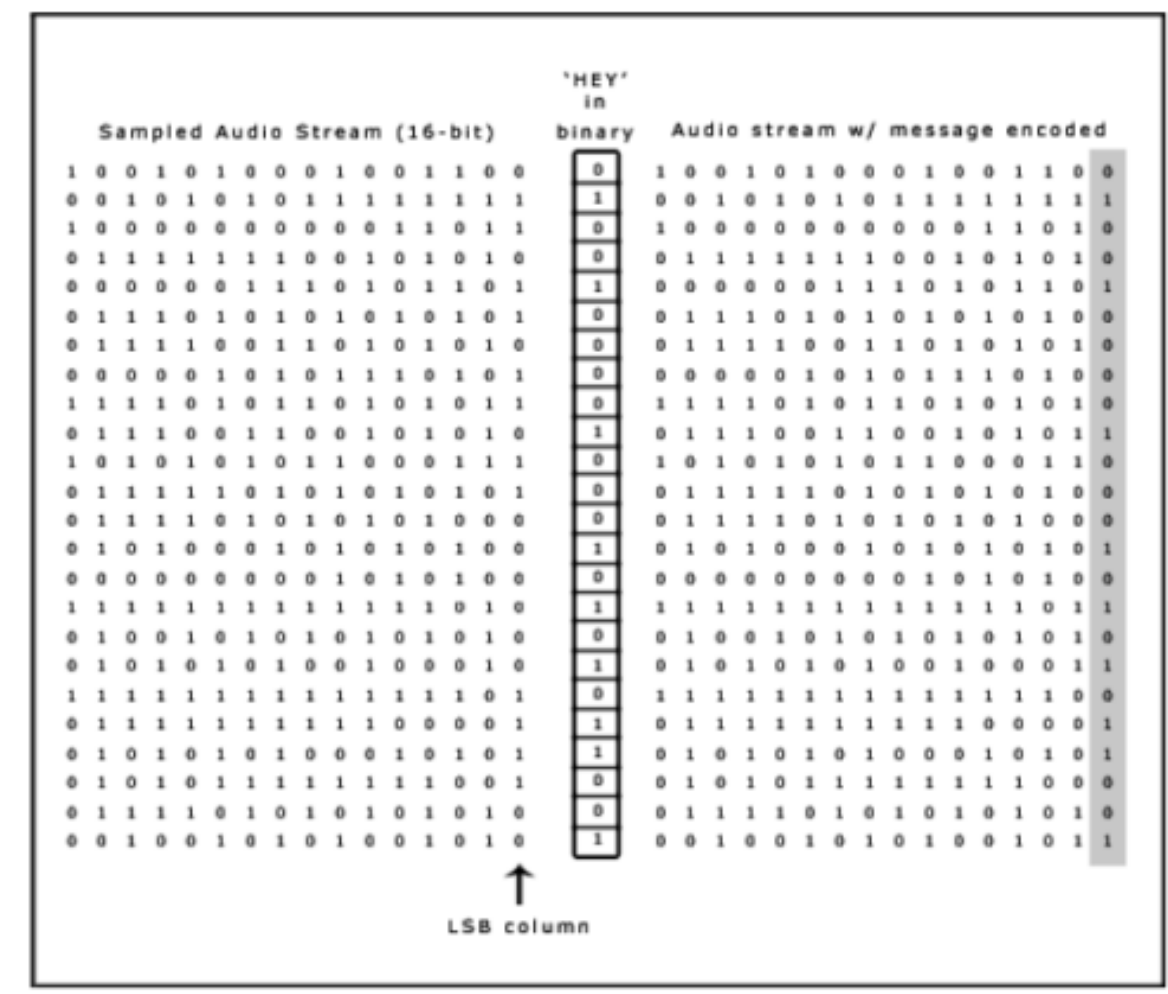

Gambar 1. Least Significant Bit 


\section{Masking and Filtering}

Kedua metode ini menyembunyikan informasi dengan cara mirip dengan penanda kertas.

\section{Transformations}

Discrete Cosine Transformation (DCT) adalah salah satu metode transformasi untuk mentransformasi $8 * 8$ blok pixel dari sebuah citra secara berurutan kedalam masing-masing koefisien DCT. Alat steganografi dapat menggunakan LSB dari koefisien DCT yang terbagibagi utnuk menyembunyikan informasi (metode JSteg).

\subsection{Kriptografi}

Kriptografi adalah seni dan ilmu untuk menjaga keamanan pesan. Kata "seni" di dalam definisi di atas berasal dari fakta sejarah bahwa pada masa-masa awal sejarah kriptografi, setiap orang mungkin mempunyai cara yang unik untuk merahasiakan pesan [8].

Terdapat 2 (dua) jenis algoritma kriptografi berdasarkan jenis kuncinya, yaitu:

a) Algoritma Simetri (konvensional)

b) Algoritma Asimetri (kunci-publik)

Algoritma Simetri, atau disebut juga dengan algoritma konvensional, adalah algoritma yang menggunakan kunci enkripsi yang sama dengan kunci dekripsinya. Disebut konvensional, karena algoritma yang biasa digunakan orang sejak berabad-abad yang lalu adalah algoritma jenis ini. Agar komunikasi tetap aman, kunci harus tetap dirahasiakan. Pesan plaintext P, misalnya SAYA dikodekan (dienkrip) menjadi ciphertext @\#\$ menggunakan password (kunci K) TES. Untuk mengembalikan ciphertext @\#\$ menjadi SAYA dilakukan proses dekripsi dengan kunci yang sama, yaitu TES. Karena kunci yang digunakan sama, maka disebut kriptografi kunci simetri.

Enkripsi adalah proses pengubahan pesan asli menjadi karakter yang tidak dapat dibaca. Sedangkan dekripsi adalah proses pengubahan karakter yang tidak dapat dibaca menjadi pesan asal. Ciphertext inilah yang biasanya dikirimkan melalui saluran internet yang rawan penyadapan.

Dengan pesan asal $\mathrm{P}$ dan kode rahasia $\mathrm{C}$ yang diperoleh dari enkripsi dengan kunci $\mathrm{K}$, kita dapat menuliskan:

$$
\mathrm{C}=\mathrm{E}_{\mathrm{k}}(\mathrm{P})
$$

Notasi ini menyatakan bahwa $\mathrm{C}$ dihasilkan oleh fungsi Enkripsi E yang dioperasikan terhadap masukan $\mathrm{P}$ dengan kunci $\mathrm{K}$. Operasi ini dilakukan oleh pengirim pesan. Penerima pesan melakukan operasi sebaliknya:

$$
\mathrm{P}=\mathrm{E}_{\mathrm{k}}(\mathrm{C})
$$

Operasi ini adalah proses dekripsi untuk kembali mendapatkan pesan asal P. Pemecah kode (cryptanalyst) sering kali hanya memiliki $\mathrm{C}$ dan harus menemukan nilai $\mathrm{P}$. 
Algoritma Simetri dapat dibagi dalam dua kategori. Jenis pertama beroperasi pada plaintext yang berupa satu bit tunggal pada satu waktu, yang disebut stream algorithms (algoritma aliran atau stream ciphers). Algoritma Asimetri, atau disebut juga dengan algoritma kunci publik, didesain sedemikian rupa sehingga kunci yang digunakan untuk enkripsi berbeda dengan kunci yang digunakan untuk dekripsi. Algoritma ini disebut kunci publik karena kunci enkripsi dapat dibuat publik yang berarti semua pihak boleh mengetahuinya. Kunci privat kadang-kadang disebut kunci rahasia. Yang termasuk algoritma asimetri adalah ECC, LUC, RSA, El Gamal dan DH.

Enkripsi dengan kunci publik $\mathrm{K}_{\mathrm{e}}$ dinyatakan sebagai:

$$
\mathrm{E}_{\mathrm{Ke}}(\mathrm{P})=\mathrm{C}
$$

Dengan kunci privat $\left(\mathrm{K}_{\mathrm{d}}\right)$ sebagai pasangan kunci publik $\left(\mathrm{K}_{\mathrm{e}}\right)$, dekripsi dengan kunci privat yang bersesuaian dapat dinyatakan dengan:

$$
\mathrm{D}_{\mathrm{Kd}}(\mathrm{C})=\mathrm{P}
$$

$\mathrm{K}_{\mathrm{e}}$ merupakan pasangan $\mathrm{K}_{\mathrm{d}}$. Artinya tidak ada $\mathrm{K}_{\mathrm{d}}$ lain yang dapat digunakan untuk melakukan dekripsi kode $\mathrm{C}$ yang merupakan hasil enkripsi dengan kunci $\mathrm{K}_{\mathrm{e}}$. Sebaliknya, pesan dapat dienkripsi dengan kunci privat dan didekripsi dengan kunci publik. Metode ini digunakan pada skema tanda tangan digital. Artinya kunci privat dan kunci publik digunakan secara berlawanan dengan tujuan yang berbeda. Sifat ini hanya berlaku untuk algoritma kunci publik tertentu semacam RSA.

\subsection{Vigenere Cipher}

Sandi Vigenère merupakan bentuk sederhana dari sandi substitusi polialfabetik. Kelebihan sandi ini dibanding sandi Caesar dan sandi monoalfabetik lainnya adalah sandi ini tidak begitu rentan terhadap metode pemecahan sandi yang disebut analisis frekuensi. Setiap huruf teks terang digantikan dengan huruf lain yang memiliki perbedaan tertentu pada urutan alfabet. Misalnya pada sandi Caesar dengan geseran 3, A menjadi D, B menjadi E and dan seterusnya. Sandi Vigenère terdiri dari beberapa sandi Caesar dengan nilai geseran yang berbeda. Untuk menyandikan suatu pesan, digunakan sebuah tabel alfabet yang disebut tabel Vigenère (Gambar 2).

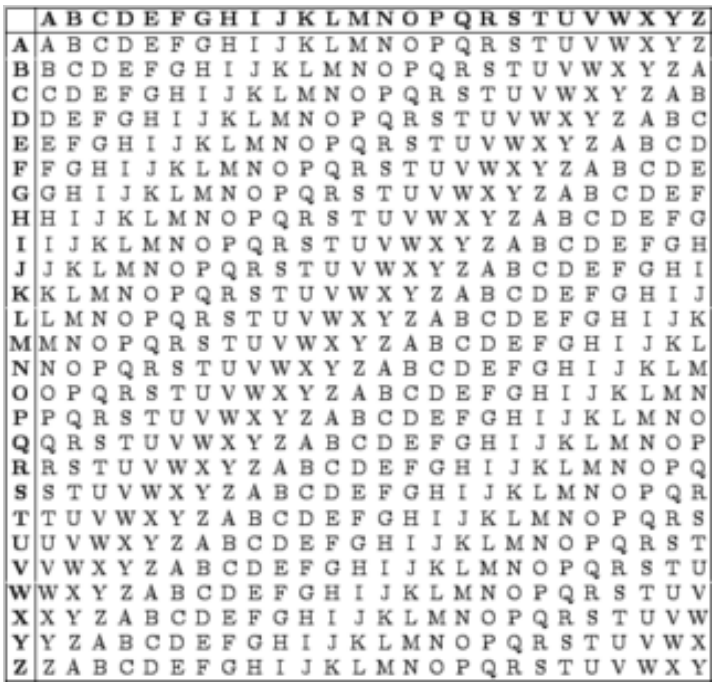

Gambar 2. Vigenere Cipher 
Misalnya, teks terang yang hendak disandikan adalah perintah "SERBUBERLIN". Sedangkan kata kunci antara pengirim dan tujuan adalah "PIZZA". Kata "PIZZA" diulang sehingga jumlah hurufnya sama banyak dengan teks terang:

\section{PIZZAPIZZAP}

Huruf pertama pada teks terang, $\mathrm{S}$, disandikan dengan menggunakan baris berjudul $\mathrm{P}$, huruf pertama pada kata kunci. Pada baris $\mathrm{P}$ dan kolom $\mathrm{S}$ di tabel Vigenère, terdapat huruf H. Demikian pula untuk huruf kedua, digunakan huruf yang terletak pada baris I (huruf kedua kata kunci) dan kolom E (huruf kedua teks terang), yaitu huruf M. Proses ini dijalankan terus sehingga:

\section{Teks terang: SERBUBERLIN}

\section{Kata kunci: PIZZAPIZZAP}

Teks bersandi: HMQAUQMQKIC

Proses sebaliknya (disebut dekripsi), dilakukan dengan mencari huruf teks bersandi pada baris berjudul huruf dari kata kunci. Misalnya, pada contoh di atas, untuk huruf pertama, kita mencari huruf $\mathrm{H}$ (huruf pertama teks tersandi) pada baris $\mathrm{P}$ (huruf pertama pada kata kunci), yang terdapat pada kolom S, sehingga huruf pertama adalah S. Lalu M terdapat pada baris I di kolom E, sehingga diketahui huruf kedua teks terang adalah E, dan seterusnya hingga didapat perintah "SERBUBERLIN".

Enkripsi (penyandian) dengan sandi Vigenère juga dapat dituliskan secara matematis, dengan menggunakan penjumlahan dan operasi modulus, yaitu:

$$
C i=(P i+K i) \bmod 26 .
$$

$C i=$ nilai ascii dari karakter ciphertext ke- $i$

$P_{i}=$ nilai ascii dari karakter plaintext ke- $i$

$K_{i}=$ nilai ascii dari karakter kunci ke- $i$

Sedangkan proses dekripsi dengan sandi Vigenere dituliskan secara matematis sebagai berikut,

$$
P i=(C i-K i) \bmod 26 \text {. }
$$

$C i=$ nilai ascii dari karakter ciphertext $\mathrm{ke}-\mathrm{i}$

$P_{i}=$ nilai ascii dari karakter plaintext ke- $i$

$K_{i}=$ nilai ascii dari karakter kunci ke- $i$

Angka modulo 26 di atas, digunakan apabila jumlah karakter yang ingin diproses hanya berjumlah 26 karakter. Apabila karakter yang ingin diproses adalah semua karakter ASCII yang berjumlah 256 karakter, maka rumus yang digunakan adalah modulo 256. 


\section{Metode Penelitian}

Algoritma enkripsi disesuaikan dengan metode yang digunakan dalam membangun system yaitu metode Vigenere Cipher. Proses penyandian dan penyisipan pesan teks dengan metode affine cipher dan Metode LSB Gambar 3.

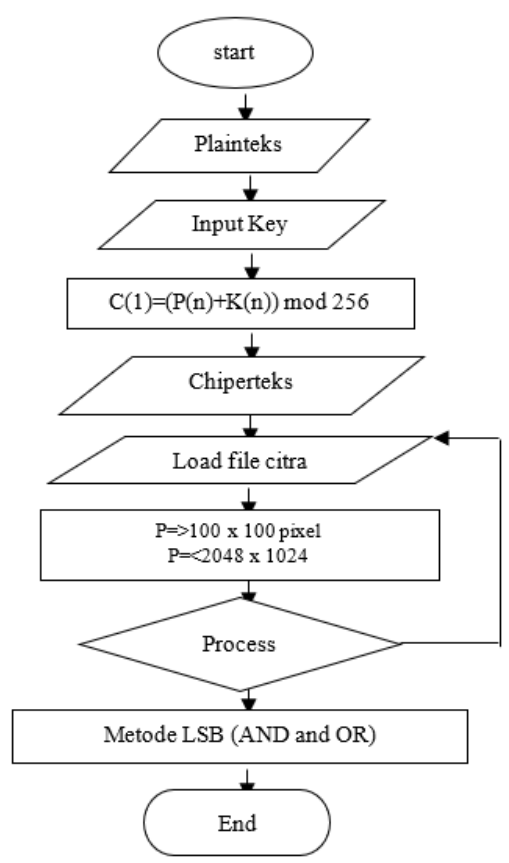

Gambar 3. Flowchart Penyandian

Algoritma ekstraksi merupakan proses untuk mendapatkan kembali pesan teks dari citra setelah dilakukan penyisipan. Skema proses penyisipan pesan pada citra digital Gambar 4.

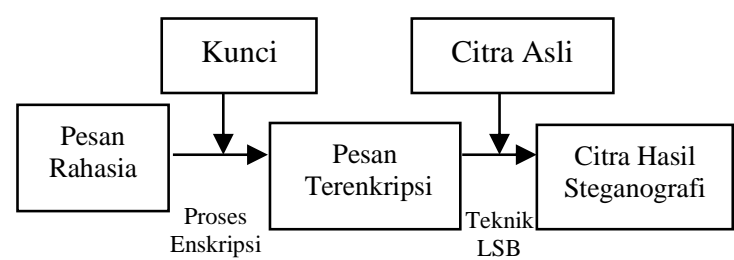

Gambar 4. Skema Proses Penyisipan Pesan

\section{Hasil dan Pembahasan}

Studi Kasus :

Misalkan pesan yang akan disisipkan adalah "Niria", sedangkan kunci yang digunakan adalah "K", maka proses enkripsi pesan dengan menggunakan metode Vigenere Cipher :

1. Karakter Pesan ke-1 = 'N'

$\mathrm{P}(1)=$ kode ascii dari ' $\mathrm{N} '=78$ 
Kunci $=$ 'K'

$\mathrm{K}(1)=$ kode ascii dari ' $\mathrm{K}$ ' $=75$

$\mathrm{C}(1)=(\mathrm{P}(1)+\mathrm{K}(1)) \bmod 256$

$\mathrm{C}(1)=(78+75) \bmod 256$

$\mathrm{C}(1)=153$, diubah ke karakter $={ }^{\mathrm{TM}}$

2. Karakter Pesan ke-2 = 'i'

$\mathrm{P}(2)=$ kode ascii dari ' $\mathrm{i}$ ' $=105$

Kunci $=$ 'K'

$\mathrm{K}(1)=$ kode ascii dari " $\mathrm{K} "=75$

$\mathrm{C}(2)=(\mathrm{P}(2)+\mathrm{K}(2)) \bmod 256$

$C(2)=(105+75) \bmod 256$

$\mathrm{C}(2)=180$, diubah ke karakter $={ }^{\prime}$

3. Karakter Pesan ke-3 = ' $r$ '

$\mathrm{P}(3)=$ kode ascii dari ' $\mathrm{r}$ ' $=114$

Kunci $=$ 'K'

$\mathrm{K}(3)=$ kode ascii dari ' $\mathrm{K}$ ' $=75$

$\mathrm{C}(3)=(\mathrm{P}(3)+\mathrm{K}(3)) \bmod 256$

$C(3)=(114+75) \bmod 256$

$\mathrm{C}(3)=189$, diubah ke karakter $=1 / 2$

4. Karakter Pesan ke-4 = 'i'

$\mathrm{P}(4)=$ kode ascii dari ' $\mathrm{i}$ ' $=105$

Kunci $=$ 'K'

$\mathrm{K}(4)=$ kode ascii dari ' $\mathrm{K}$ ' $=75$

$\mathrm{C}(4)=(\mathrm{P}(4)+\mathrm{K}(4)) \bmod 256$

$C(4)=(105+75) \bmod 256$

$\mathrm{C}(4)=180$, diubah ke karakter $=$ '

5. Karakter Pesan ke-5 = 'a'

$\mathrm{P}(5)=$ kode ascii dari 'a' $=97$ 


$$
\begin{aligned}
& \text { Kunci }=\text { 'K' } \\
& \mathrm{K}(5)=\text { kode ascii dari "K" }=75 \\
& \mathrm{C}(5)=(\mathrm{P}(5)+\mathrm{K}(5)) \bmod 256 \\
& \mathrm{C}(5)=(97+75) \bmod 256 \\
& \mathrm{C}(5)=172, \text { diubah ke karakter }=\neg
\end{aligned}
$$

Dengan demikian, hasil enkripsi dari pesan "Niria" dengan menggunakan kunci berupa "K" adalah "TM'1/2' $\neg "$. Selanjutnya, ubah setiap karakter dari pesan cipher ke biner, dan sisipkan bit-bit ke citra digital dengan menggunakan teknik LSB, sebagai berikut:

1. Ubah ciphertext ke biner.

Karakter ke-1 = '• TM ', kode ascii $=153$, diubah ke biner $=10011001$

Karakter ke-2 $={ }^{\prime}{ }^{\prime}$, kode ascii $=180$, diubah ke biner $=10110100$

Karakter ke-3 =, $1 / 2$ ', kode ascii $=189$, diubah ke biner $=10111101$

Karakter ke-4 =' ', , kode ascii $=180$, diubah ke biner $=10110100$

Karakter ke-5 $={ }^{\prime} \rightarrow$ ', kode ascii $=172$, diubah ke biner $=10101100$

Hasil pengubahan ciphertext ke biner adalah sepanjang 88 bit biner, yaitu: 1001100110110100 101111011011010010101100

2. Sisipkan bit-bit biner dari ciphertext secara berurutan pada bit paling terakhir (Least Significant Bit

/ LSB) dari citra, dimulai dari piksel paling kiri atas, Tabel 1.

Tabel 1 Proses Penyisipan Bit-Bit Biner Ke Piksel Citra

\begin{tabular}{|l|l|l|l|}
\hline $\begin{array}{c}\text { Nilai Piksel } \\
\text { Citra }\end{array}$ & $\begin{array}{c}\text { Konversi } \\
\text { Dalam Biner }\end{array}$ & $\begin{array}{c}\text { Bit } \\
\text { Biner }\end{array}$ & $\begin{array}{c}\text { Hasil } \\
\text { Penyisipan }\end{array}$ \\
\hline Piksel -1 & $0100010 \underline{1}$ & 1 & $\mathrm{R}=189$ \\
$\mathrm{R}=190$ & $0100110 \underline{1}$ & 0 & $\mathrm{G}=247$ \\
$\mathrm{G}=248$ & $0100101 \underline{0}$ & 0 & $\mathrm{~B}=162$ \\
$\mathrm{~B}=161$ & & & \\
\hline Piksel -2 & $0100111 \underline{1}$ & 1 & $\mathrm{R}=47$ \\
$\mathrm{R}=48$ & $0101000 \underline{1}$ & 1 & $\mathrm{G}=98$ \\
$\mathrm{G}=99$ & $0100110 \underline{1}$ & 0 & $\mathrm{~B}=40$ \\
$\mathrm{~B}=41$ & & & \\
\hline Piksel -3 & $0100011 \underline{0}$ & 0 & $\mathrm{R}=72$ \\
$\mathrm{R}=71$ & $1001111 \underline{0}$ & 1 & $\mathrm{G}=159$ \\
$\mathrm{G}=158$ & $0001110 \underline{0}$ & 1 & $\mathrm{~B}=29$ \\
$\mathrm{~B}=28$ & & & \\
\hline $\mathrm{Piksel}-4$ & $0000010 \underline{1}$ & 0 & $\mathrm{R}=4$ \\
$\mathrm{R}=5$ & $1110000 \underline{1}$ & 1 & $\mathrm{G}=224$ \\
$\mathrm{G}=225$ & $1010000 \underline{0}$ & 1 & $\mathrm{~B}=161$ \\
$\mathrm{~B}=160$ & & & \\
\hline Piksel -5 & &
\end{tabular}




\begin{tabular}{|l|l|l|l|}
\hline$R=115$ & $0110100 \underline{1}$ & 0 & $R=114$ \\
$G=32$ & $0010000 \underline{0}$ & 1 & $G=33$ \\
$B=205$ & $1100110 \underline{1}$ & 0 & $B=204$ \\
\hline
\end{tabular}

(ulangi cara yang sama hingga bit ke-48 dari cipher disisipkan pada piksel citra)

3. Citra setelah disisipkan 48 bit cipher, Gambar

\begin{tabular}{|c|c|c|c|c|}
\hline 189 & 47 & 72 & 4 & 114 \\
247 & 98 & 159 & 224 & 33 \\
162 & 40 & 29 & 161 & 204 \\
\hline 247 & 232 & 185 & 247 & 19 \\
65 & 119 & 235 & 43 & 53 \\
97 & 95 & 245 & 28 & 218 \\
\hline 44 & 229 & 249 & 242 & 122 \\
157 & 150 & 58 & 77 & 104 \\
89 & 225 & 56 & 212 & 243 \\
\hline 119 & 19 & 119 & 253 & 7 \\
249 & 112 & 32 & 67 & 203 \\
89 & 117 & 41 & 237 & 110 \\
\hline 250 & 197 & 134 & 160 & 31 \\
215 & 127 & 179 & 81 & 17 \\
59 & 149 & 108 & 97 & 118 \\
\hline 50 & 170 & 75 & 117 & 92 \\
235 & 20 & 54 & 38 & 147 \\
116 & 141 & 188 & 29 & 201 \\
\hline 85 & 178 & 206 & 165 & 6 \\
22 & 54 & 209 & 67 & 95 \\
44 & 254 & 50 & 152 & 121 \\
\hline
\end{tabular}

Gambar 5. Citra Setelah Penyisipan Bit Cipher

4. Agar dapat mengetahui panjang bit pesan yang disisipkan, maka sisipkan panjang bit pesan pada 5 piksel terakhir dari citra, sebagai berikut:

Panjang bit pesan $=48=000000000110000$ (biner)

\begin{tabular}{|c|c|c|c|c|c|}
\hline \multicolumn{3}{|l|}{ Citra } & Pjg Pesan & \multicolumn{2}{|c|}{ Hasil Penyisipan } \\
\hline Piksel-31 & $R=85$ & $=0101010 \underline{1}$ & 0 & $R=01010100$ & $=$ \\
\hline & $G=22$ & $=0001011 \underline{\overline{0}}$ & 0 & $\mathrm{G}=00010110$ & $=$ \\
\hline & $B=44$ & $=00101100$ & 0 & $B=00101100$ & $=$ \\
\hline Piksel-32 & $R=178$ & $=1011001 \underline{0}$ & 0 & $R=10110010$ & $=178$ \\
\hline & $G=54$ & $=0011011 \underline{0}$ & 0 & $\mathrm{G}=0011$ & $=$ \\
\hline & $B=254$ & $=1111111 \underline{\overline{0}}$ & 0 & $B=111$ & $=254$ \\
\hline Piksel-33 & $R=206$ & $=1100111 \underline{0}$ & 0 & $R=11001110$ & $=206$ \\
\hline & $G=209$ & $=1101000 \underline{1}$ & 0 & $\mathrm{G}=11010000$ & $=208$ \\
\hline & $B=50$ & $=0011001 \underline{\overline{0}}$ & 1 & $B=00110011$ & $=$ \\
\hline iksel-34 & $R=165$ & $=10100101$ & 0 & $R=10100100$ & $=164$ \\
\hline & $G=67$ & $=0100001 \underline{1}$ & 1 & $\mathrm{G}=01000011$ & $=$ \\
\hline & $B=152$ & $=1001100 \underline{0}$ & 1 & $B=10011001$ & $=153$ \\
\hline $21-35$ & $R=6$ & $=0000011 \underline{0}$ & 0 & $R=00000110$ & $=$ \\
\hline & $G=95$ & $=0101111 \underline{\overline{1}}$ & 0 & $\mathrm{G}=01011110$ & $=$ \\
\hline & $B=121$ & $=01111001$ & 0 & $B=01111000$ & $=120$ \\
\hline
\end{tabular}

Gambar 6. Panjang Bit Pesan

Citra akhir hasil penyisipan Gambar 7. 


\begin{tabular}{|c|c|c|c|c|}
\hline 189 & 47 & 72 & 4 & 114 \\
247 & 98 & 159 & 224 & 33 \\
162 & 40 & 29 & 161 & 204 \\
\hline 247 & 232 & 185 & 247 & 19 \\
65 & 119 & 235 & 43 & 53 \\
97 & 95 & 245 & 28 & 218 \\
\hline 44 & 229 & 249 & 242 & 122 \\
157 & 150 & 58 & 77 & 104 \\
89 & 225 & 56 & 212 & 243 \\
\hline 119 & 19 & 119 & 253 & 7 \\
249 & 112 & 32 & 67 & 203 \\
89 & 117 & 41 & 237 & 110 \\
\hline 250 & 197 & 134 & 160 & 31 \\
215 & 127 & 179 & 81 & 17 \\
59 & 149 & 108 & 97 & 118 \\
\hline 50 & 170 & 75 & 117 & 92 \\
235 & 20 & 54 & 38 & 147 \\
116 & 141 & 188 & 29 & 201 \\
\hline 84 & 178 & 206 & 164 & 6 \\
22 & 54 & 208 & 67 & 94 \\
44 & 254 & 51 & 153 & 120 \\
\hline
\end{tabular}

Gambar 7. Citra Hasil Penyisipan

Tampilan form, Gambar 8, form utama pesan teks yang dihasilkan merupakan tampilan yang menyerupai bentuk perancangan form sebelumnya.

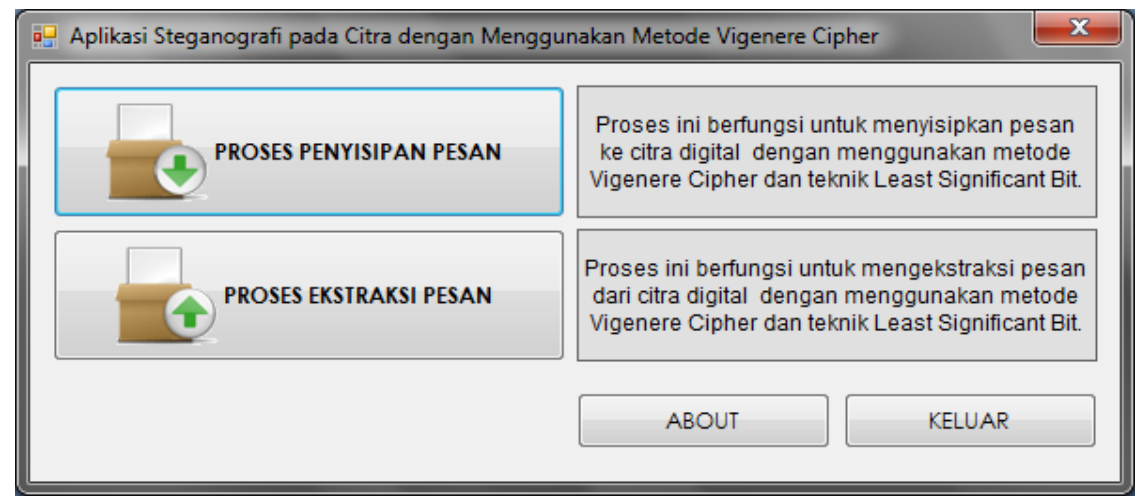

\section{Gambar 8. Form Utama}

Setelah mendapatkan hasil tampilan perangkat lunak, selanjutnya dilakukan pengujian terhadap sistem tersebut. Adapun metode pengujian sistem yang penulis lakukan adalah metode black box dimana pengujian dibagi dalam beberapa tahapan.

Pengujian proses penyisipan pesan teks ke citra

Pengujian proses penyisipan pesan teks dilakukan untuk melihat apakah masih terdapat galat (error) pada saat proses penyisipan dilakukan pada form penyisipan. Dalam pengujian ini, dilakukan proses penyisipan terhadap sebuah file teks yang berisi pesan sebagai berikut :

Pesan teks $="$ niria $"$

Kunci $=$ "K"

Langkah pertama yang harus dilakukan adalah buka aplikasi steganografi vigenere cipher kemudian load terhadap citra yang digunakan untuk menyimpan file teks. 


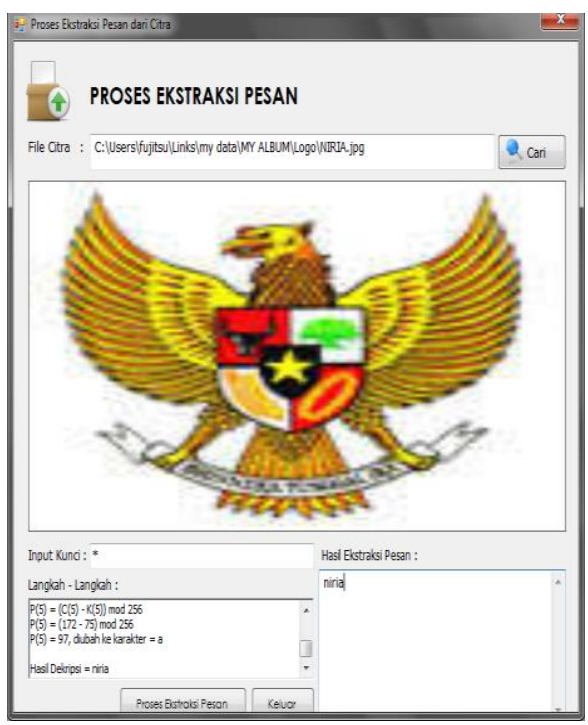

Gambar 9. Form Pengujian

Jika dilihat dengan kasat mata, maka perbedaan terhadap kedua citra tersebut tidak akan tampak. Tidak terlihat sedikitpun perbedaan tapi jika dilihat dari ukuran file citra awal dengan ukuran file citra akhir akan terdapat perbedaan ukuran file. Sistem hanya bisa melakukan penyisipan pada pesan yang berformat txt. Sedangkan untuk citranya harus berformat bitmap $(B M P)$ dan JPEG. Metode Vigenere Cipher melakukan proses enkripsi dari teks ke teks. Ukuran file citra dibatasi pada ukuran minimal 100 X 100 pixel, dan maksimal 2048 X 1024 piksel selain itu system tidak dapat memprosesnya.

\section{Kesimpulan}

1. Proses penyandian dan penyisipan pesan dengan metode Vigenere Cipher dan LSB yaitu langkah awal input file teks dan kata kunci, seterusnya file teks dan kata kunci diubah ke dalam bilangan decimal, seterusnya diproses sesuai dengan rumus Vigenere Cipher diharapkan data yang dikirim tidak mudah dibaca oleh pihak ketiga.

2. Algoritma Vigenere Cipher dan teknik LSB (Last Significant Bit) dapat dijadikan sebagai solusi untuk keamanan pesan rahasia yang disisipkan ke dalam image, dan dapat diungkap kembali sama persis dengan bentuk asli dan tidak mengalami kerusakan sedikitpun.

3. Merancang aplikasi pengamanan data dengan metode Vigenere Cipher dan LSB yaitu dengan langkah awal merancang form penyisipan dan ektsraksi, setelah itu merancang form untuk menampilkan hasil penyisipan dan form untuk menampilkan hasil ektraksi.

\section{DAFTAR REFERENSI}

[1] Antonius Erick Handoyo, De Rosal Ignatius Moses Setiadi, Eko Hari Rachmawanto, Christy Atika Sari, AjibSusanto, Teknik Penyembunyian dan Enkripsi Pesan pada Citra Digital dengan Kombinasi Metode LSB dan RSA, Jurnal Teknologi dan Sistem Komputer, 6(1),,3743, February 2018. 
[2] Ali Akbar Lubis, Ng Poi Wong, Irfan Arfiandi, V. Immanuel Damanik4 , Adithya Maulana, Steganografi pada Citra dengan Metode MLSB dan Enkripsi Triple Transposition Vigenere Cipher, VOL 16, NO 2, OKTOBER 2015.

[3] Darmayanti1, Awang Harsa.K, Sistem Steganografi Pada Citra Digital Menggunakan Least Significant Bit, Prosiding Seminar Sains dan Teknologi FMIPA Unmul Vol. 1 No. 1 Juli 2016.

[4] Indra Gunawan, Sumarno, Eka Irawan, Heru Satria Tambunan, Pengamanan Berkas Dokumen Menggunakan Fungsi Algoritma Steganografi LSB, urnal Informatika Mulawarman, Vol. 12, No. 2 September 2017.

[5] Rohmat Nur Ibrahim, Ilham M.S, PERANCANGAN APLIKASI STEGAKRIP DENGAN METODE LSB DAN ALGORITMA RSA BERBASIS WEB, Jurnal Computech \& Bisnis, Vol. 11, No 1, , 98-109, Desember 2017.

[6] Irham Mu'alimin Arrijal, Rusdi Efendi, Boko Susilo, PENERAPAN ALGORITMA KRIPTOGRAFI KUNCI SIMETRIS DENGAN MODIFIKASI VIGENERE CIPHER DALAM APLIKASI KRIPTOGRAFI TEKS, Jurnal Pseudocode, Volume III Nomor 1, Februari 2016.

[7] Efrandi, Asnawati, Yupiyanti, APLIKASI KRIPTOGRAFI PESAN MENGGUNAKAN ALGORITMA VIGENERE CIPHER, Jurnal Media Infotama Vol. 10 No. 2, September 2014.

[8] Syaiful Anwar, Indra Nugroho, Asep Ahmadi, Implementasi Kriptografi Dengan Enkripsi Shift Vigenere Cipher Serta Checksum Menggunakan CRC32 Pada Data Text, Jurnal Sistem Informasi Volume.2, 2015. 